\title{
PROCES PLANOWANIA I PODEJMOWANIA DECYZJI NA PRZYKŁADZIE PRZEDSIĘBIORSTW Z WOJEWÓDZTWA KUJAWSKO-POMORSKIEGO
}

Z a r y s tre ś c i: Celem artykułu jest pokazanie, jak ważne i złożone są procesy planowania i podejmowania decyzji dotyczących organizacji oraz jakie błędy popełniają decydenci, wybierając spośród kilku zróżnicowanych rozwiązań. Badania przeprowadzone zostały w celu określenia, w jaki sposób w przedsiębiorstwach odbywa się proces planowania oraz jak podejmuje się decyzje. Pomiar został przeprowadzony w okresie od grudnia do maja 2011 roku wśród pracowników przedsiębiorstw z województwa kujawsko-pomorskiego. Instrumentem pomiarowym był kwestionariusz ankiety, obejmujący próbę 320 osób. W artykule autorka przedstawia również psychospołeczną stronę procesów, która odgrywa znaczącą rolę w omawianym zagadnieniu.

Słow a kluc zow e: podejmowanie decyzji; planowanie; cele; reguły decyzyjne K 1 as y fikacja J E L: L26, O32

\section{WSTĘP}

Planowanie i podejmowanie decyzji to jedne z podstawowych i niezwykle znaczących elementów działalności przedsiębiorstw, które mają wpływ

* Adres do korespondencji: Uniwersytet Mikołaja Kopernika w Toruniu, Wydział Nauk Ekonomicznych i Zarządzania, ul. Gagarina 13a, 87-100 Toruń, e-mail:skarbam@doktorant.umk.pl. 
na jego skuteczność, a co za tym idzie na wyniki. Tworzą one podstawy osiągania większych zysków i nadają właściwy kierunek rozwojowi organizacji. Obecnie przedsiębiorstwa dążą do bycia na topie i prześcigają się w stosowaniu nowoczesnych technik zarządzania. Używają mediów społecznościowych do zdobywania coraz większej rzeszy klientów i śledzenia zmian w ich oczekiwaniach. Stosują praktyki społecznie odpowiedzialne, by wyjść naprzeciw wymaganiom wszystkich interesariuszy. Bardzo często zapominają jednak o podstawowych elementach działania firmy - wspomnianych na samym początku planowaniu i strategicznym podejmowaniu decyzji. W procesach tych należy pamiętać, że czasami poświęcenie krótkookresowych zysków może nieść ze sobą daleko idącą rekompensatę. Przedsiębiorstwa, nie biorąc tego faktu pod uwagę, patrzą jedynie na przysłowiowe „tu i teraz”. Możliwe, że takie zachowanie jest powodem upadku większości firm w pierwszym roku działalności [www.is.uw.edu.pl/ wp-content/uploads/21_Bierzynski.pdf]. Dlaczego uważa się, że planowanie jest tak istotne dla działania firmy? Odpowiedź na to pytanie jest prosta i wypływa z samej jego definicji, mówiącej o często przykrych konsekwencjach dla przedsiębiorstwa, wynikających z braku określonego konceptu.

\section{ISTOTA I ZNACZENIE PLANOWANIA I PODEJMOWANIA DECYZJI}

Każda firma osiąga w mniejszym lub większym stopniu cele, które są rezultatem planowania i podejmowania decyzji. Oznacza to, że owe procesy są priorytetowe i wymagają poświęcenia czasu oraz zwrócenia szczególnej uwagi managementu każdego przedsiębiorstwa. Według H. A. Simona proces podejmowania decyzji jest bardzo złożony i nie taki oczywisty. jak mogłoby się wydawać. Firmy, chcąc osiągnąć przewagę konkurencyjną, powinny potrafić określić potrzebę podjęcia jakiejkolwiek decyzji, zidentyfikować problem, ale - co najważniejsze - zrozumieć go, sformułować rozwiązanie i zrealizować, biorąc pod uwagę wszelkie szanse i zagrożenia. Procesy planowania $\mathrm{w}$ ramach przedsiębiorstwa ze względu na kryterium ważności powinny być podejmowane w różnych horyzontach czasowych, gdzie cele krótkookresowe mają prowadzić do spełnienia celów strategicznych. Przedsiębiorstwa jednak rzadko tworzą zarys zdarzeń, jakie mają zajść w dłuższym okresie. Nie można nawet mówić o coraz lepszym wykorzystaniu nowoczesnych narzędzi służących do tworzenia planów i ich realizacji. 
Pytając kierowników wyższego szczebla, w jaki sposób tworzona jest strategia firmy, w wielu wypadkach usłyszeć można bardzo niesatysfakcjonującą odpowiedź, że strategia powstaje, bo takie są wymagania, lub że trzeba ją umieścić na stronie internetowej. Dodatkowym problemem jest to, że plany firm nie są kompatybilne ze wspomnianymi już wcześniej oczekiwaniami konsumentów. W ostatnim czasie bardzo „modną" i rozgłaszaną przez wszystkich koncepcją jest idea społecznej odpowiedzialności biznesu. W związku z tym przedsiębiorstwa, planując sprzedaż, wybór surowców i materiałów czy miejsca produkcji, powinny wziąć pod uwagę, że oczekiwania klientów będą związane z CSR-em. W konsekwencji, nie posiadając pomysłu, w jaki sposób przekazać klientom produkty społecznie odpowiedzialne, natomiast mając działania, które można określić jako „brak planów”, wiele przedsiębiorstw boryka się z kłopotami z tego wynikającymi. Przykładem mogą być tutaj przedsiębiorstwa z branży odzieżowej, które zostały oskarżone o to, że są jednym z ważniejszych ogniw przyczyniających się do wylesiania terenów zielonych. Na takie oskarżenie zareagowała większość marek, jednak jako pierwsi o wprowadzeniu polityki naprawy poinformowali menadżerowie firmy Levi Strauss \& Co., którzy wycofali się z kontaktów z dostawcami proponującymi niepewne, a tym bardziej zwracające uwagę obrońców zieleni włókna celulozowe [http://www.ekonsument.pl/a66763_czy_moda_kocha lasy .html]. Podobna sytuacja zaistniała w przemyśle meblarskim, a konkretnie w firmie IKEA. Przedsiębiorstwo zostało oskarżone o produkcję wyrobów papierniczych z drzew lasów tropikalnych, czym przyczyniło się do deforestacji terenów równikowych. [http://www.ekonsument.pl/ a66758_analiza_wlokien_potwierdzila_ze_notatniki_ikea_zawieraja celuloze_z_lasow_tropikalnych.html]. To, czy IKEA działała świadomie, czy po prostu nie planując wszystkiego popełniła karygodny błąd, nie zostało skomentowane, jednak wpłynęło na reputację przedsiębiorstwa.

Każde przedsiębiorstwo ma za zadanie pogodzić cele krótko- $\mathrm{z}$ długookresowymi. Oczywiście najważniejszym założeniem dla podmiotu gospodarczego jest osiągnięcie jak najwyższego zysku. Jednak główny cel nie może przysłonić innych, takich jak na przykład zadowolenie pracowników, które wpływa na jakość wykonywanych zadań. Bardzo często zdarza się, że w przedsiębiorstwach, dążąc do maksymalizacji wyników, nakłada się na pracowników określone plany sprzedażowe, które są niemożliwe do wykonania. Powoduje to frustrację, ponieważ zatrudnieni wiedzą już na początku miesiąca, że nie są w stanie spełnić nałożonych 
na nich oczekiwań. W związku z tym wychodzą z założenia, że nie warto się starać, bo obiecanej za wykonanie planu premii nie otrzymają. Doprowadza to do słabej jakości pracy, braku motywacji i niezadowolenia. Stwarzanie więc celów idealnych dla jednej ze stron (w opisanym przypadku dla kierownictwa) prowadzi do oporu pozostałych zainteresowanych, a w rezultacie do braku ich realizacji [Załęski, 1993, s. 29].

Doskonałymi przykładami podkreślonego już stwarzania nierealizowalnych celów są banki, nakładające na swoich pracowników niebotycznie wysokie plany sprzedażowe na każdy miesiąc. Nie dość, że minimum produktów finansowych w wielu instytucjach, jakie pracownik ma zadanie sprzedać, jest kolosalna, to dodatkowo co jakiś czas nakładane są ponadprogramowe wytyczne, bez których spełnienia nie można liczyć na premię. Temat ten został już poruszony przez Związek Banków Polskich, który zorganizował nawet konkurs o nazwie „Etyka w finansach”, dzięki któremu neguje się między innymi motywację słowami: Jesteście zerami sprzedażowymi. Na początku miesiąca jesteście nikim. Jesteście tak dobrzy jak wasz ostatni kwartat [Stroński, 2011].

Opisując powyższy przypadek, od razu nasuwa się pytanie, czy osoby zarządzające, chcąc doprowadzić do realizacji założeń, mają ogólne, akceptowalne plany, czyli sposoby działania prowadzące do określonych celów [Zieleniewski, 1969, s. 209]. Analizując literaturę przedmiotu, wymienić można cechy, jakie powinien zawierać każdy plan. Są nimi przede wszystkim [Kotarbiński 1960, s. 165]:

- komunikatywność,

- wykonalność,

- zgodność wewnętrzna,

- racjonalność,

- szczegółowość,

- elastyczność.

Kiedy plan charakteryzuje się takimi kryteriami, to zazwyczaj nie ma problemu z odpowiedzialnością za niego. Generalnie nie ma zasady, kto w przedsiębiorstwie powinien odpowiadać za realizację poszczególnych przedsięwzięć. Czasem jednak powołuje się specjalny personel planistyczny, który pomaga w pracy poszczególnym jednostkom, jak również przygląda się określonemu problemowi z dużo szerszej perspektywy. Planistyczny zespół zadaniowy zostaje utworzony przede wszystkim w związku z niezwykłymi okolicznościami. Jest on zazwyczaj rozwiązywany po spełnieniu swoich obowiązków. Jak pokazuje praktyka, najczęściej jednak odpowiedzialność wykonawcza spoczywa na menadżerach lub dyrekto- 
rach, którzy z kolei odpowiadają przed najwyższymi szczeblami władzy w przedsiębiorstwie [Tyrała, 2001, s. 153].

W procesach planowania oraz podejmowania decyzji mogą pojawiać się różnorodne bariery hamujące. Podstawową jest nieodpowiednie dobranie celów lub sposobów ich realizacji dla danego przedsiębiorstwa. Wykonanie takich założeń może okazać się niemożliwe. Nie można winić w takiej sytuacji odpowiedzialnych pracowników, może się bowiem okazać, że angażowali się oni i wykazywali w pełni własną inicjatywę, a brak ostatecznych pozytywnych wyników uzależniony jest od czynników zewnętrznych. Często powodem jest dynamiczne i złożone otoczenie. Problem nie leży tutaj wewnątrz organizacji i często decydenci nie mają wpływu na rozwój sytuacji. Firma nie może przewidzieć, jak zachowywać się będzie konkurencja $\mathrm{i}$ jakie zmiany chociażby technologiczne nastąpią w najbliższym okresie. Niezwykle ważnymi ograniczeniami, które spowodować mogą fiasko przedsięwzięć, są: brak funduszy, polityka państwa, w tym obowiązujące prawo czy lokalizacja przedsiębiorstwa [Tyrała, 2001, s. 231-233].

Bardzo często to kierownictwo wyższego szczebla odpowiedzialne jest za to, w jaki sposób doprowadzić przedsiębiorstwo do osiągnięcia oczekiwanych rezultatów. Oczekuje się również, że sposób, w jaki będą postępować, będzie przemyślany i wpłynie na sukces całego przedsięwzięcia. W literaturze przedmiotu wymienia się bardzo wiele sposobów doboru odpowiednich rozwiązań. Z obserwacji jednak wynika, że zazwyczaj dla firm nie są one znane, a wszelkie wybory są efektem działań intuicyjnych albo opartych na wcześniejszych doświadczeniach. Decydenci nie zawsze jednak biorą pod uwagę fakt, że sposób, który został zastosowany do jednego zadania, nie będzie odpowiedni dla innych. Zmieniają się bowiem okoliczności, realia rynkowe, a przede wszystkim różne są zmienne dotyczące różnego rodzaju punktów docelowych. Najczęściej spotykaną i wykorzystywaną w przedsiębiorstwach regułą decyzyjną jest reguła eliminacji, która polega na odrzuceniu wszystkich elementów, które nie są w stanie spełnić oczekiwanych przesłanek. Menadżer może skupić się na najbardziej trafnych rozwiązaniach [Kuczmera-Ludwiczyńska, Romanowska, Sopińska, Wachowiak, 2001, s. 152-154]. Istnieje jednak niebezpieczeństwo, że kryteria wyboru tak się zawężą, że w rezultacie decydent nie znajdzie żadnego „dobrego" rozwiązania, a co za tym idzie - firma nie będzie mogła ogłosić werdyktu $\mathrm{w}$ danej sprawie. $Z$ drugiej strony jednak reguła ta nie pozwala na podjęcie pochopnej decyzji i zmusza do szukania nowych rozwiązań, jeżeli dotychczasowe propozycje będą nietrafne. Badając powyższą kwestię w przedsię- 
biorstwach, łatwo można rozpoznać, że kierownictwo nie potrafi nazwać sposobu, który wykorzystuje. Nie zdaje sobie również sprawy, że jest to w ogóle reguła decyzyjna.

Trudną do rozwiązania dla osób decydujących w przedsiębiorstwie sytuacją jest konieczność podjęcia racjonalnej decyzji w warunkach konfliktu. W tym wypadku zadaniem menadżerów jest najpierw rozwiązanie konfliktu, a dopiero później przystąpienie do procesu decyzyjnego. W innym wypadku pogodzenie tych dwóch kwestii nie dość, że nie jest możliwe, to może doprowadzić do przykrych konsekwencji, nie tylko natury interpersonalnej. Decyzje podejmowane w warunkach konfliktu cechuje zazwyczaj duża niepewność spowodowana niemożnością przewidzenia zachowań ludzkich. Podejmowanie decyzji w warunkach konfliktu nie sprzyja negocjacjom, gdyż trzeba doprowadzić do konsensusu między dwiema (lub więcej) wrogo nastawionymi do siebie stronami. Inną kwestią łączącą się z owym problemem jest to, że dla decydenta bardzo ważna jest akceptacja podjętej już decyzji. Kiedy przedsiębiorstwo znajduje się w sytuacji problemowej, rezygnuje się często z rozwiązań najlepszych na rzecz takich, na które choć po części zgodzą się inne osoby biorące udział w całym procesie.

Drugą podobną sytuacją jest podejmowanie decyzji w warunkach kryzysu. Otóż kryzysem w organizacji nazywamy sytuację, w której wskutek gwałtownego spiętrzenia różnorodnych trudności zagrożona jest realizacja jej podstawowych funkcji [Czermiński, Czermiński, Łatowska, 2001, s. 83-90]. Ponadto sytuacja kryzysowa występuje wtedy, gdy kierownictwo traci swoją dotychczasową pozycję i powstają konflikty między pracownikami. Kryzys $\mathrm{w}$ znacznym stopniu utrudnia pracę $\mathrm{w}$ organizacji, także tą związaną z podejmowaniem decyzji. W związku z tym w procesie decyzyjnym mogą pojawić się ograniczenia poznawcze, odosobnienie kierownictwa, obniżenie motywacji i konflikty. Rezultatem tego jest niska jakość podjętych decyzji lub ich brak.

Należy pamiętać, że proces planowania jest powiązany zarówno z otoczeniem wewnętrznym, jak i zewnętrznym przedsiębiorstwa. Jego interesariuszami będą nie tylko pracownicy, którzy interesują się zmianami zachodzącymi w ich miejscu zatrudnienia, ale także klienci czy lokalna społeczność. Planowanie bowiem nie odnosi się jedynie do określenia wielkości produkcji czy rodzaju oferowanego asortymentu. Każdy krok przedsiębiorstwa powinien być przemyślany i przekalkulowany. Nie zawsze jednak decydenci postawieni są przed łatwym wyborem. Zwłaszcza w dobie wysokiej konkurencyjności, gdzie przedsiębiorstwa powinny posiadać umiejętność dostrzegania oczekiwań klientów i dostarczania im maksy- 
malnej satysfakcji, podejmowanie decyzji pozwalające na utrzymywanie długotrwałych relacji rynkowych, a zarazem stwarzające najlepsze pole do działania firmy może okazać się niezwykle trudne[Sudolska, 2013, s. 26].

Zachowanie osób podejmujących decyzje w sytuacjach skomplikowanych różni się od standardowych zachowań. Według teorii opisywanych w literaturze przedmiotu podejmowanie trudnych decyzji obciąża aparat wykonawczy i poznawczy człowieka, przez co wpływa na jakość decyzji i czas potrzebny do wprowadzania ich w życie. W procesie decyzyjnym występują kolejno po sobie trzy fazy. Pierwsza z nich to faza mobilizacji, gdzie wytwarza się napięcie emocjonalne i powstaje najwięcej pomysłów. Niestety, w stadium tym osoby decydujące nie są w stanie przewidzieć wszystkich złych konsekwencji swoich działań. Drugim etapem jest rozstrojenie, kiedy pojawiają się trudności i nawet najbardziej widoczne niekorzystne konsekwencje nie są dostrzegalne przez osobę wybierającą. Ostatnią fazą jest deformacja i tutaj niemożliwe jest podjęcie praktycznie żadnej racjonalnej decyzji. Działania powzięte w tym momencie w dużej mierze są efektem przypadku i działania emocji, które nie są sprzyjające [Kozielecki, 1992, s. 357-359].

Decydenci, tworząc plany dla organizacji, muszą uwzględniać całe otoczenie i dostosowywać swoje założenia do potrzeb każdego uczestnika rynku związanego z przedsiębiorstwem. W związku z tym posiadać muszą odpowiednie kompetencje, pozwalające na takie kroki. Wiadomo bowiem, że na złe decyzje wpływają przede wszystkim ograniczenia związane $\mathrm{z}$ wiedzą i umiejętnościami. Jedną z cech, która może powodować niewłaściwe podejmowanie decyzji, jest krótkowzroczność poznawcza [Kahn, 1976]. O jej występowaniu może świadczyć to, że decydent nie bierze pod uwagę wszystkich determinant mających wpływ na występowanie problemu. Rozwiązaniem w takim przypadku może być angażowanie wszystkich pracowników do stworzenia novum w przedsiębiorstwie. Model takiej pracy mógłby opierać się na integracji, interakcji oraz niezwykle rozwiniętej komunikacji. Menadżerowie jednak bardzo często popełniają błąd przypisywania podwładnym swojego sposobu myślenia i poglądów. Powoduje to sytuację, w której pracownicy traktowani są jako osoby niepotrafiące znaleźć lepszego rozwiązania ani wygenerować innego pomysłu niż ich przełożony. 


\section{PSYCHOSPOŁECZNA STRONA PLANOWANIA I PODEJMOWANIA DECYZJI}

Bardzo istotną kwestię $\mathrm{w}$ procesach planowania i podejmowania decyzji stanowi aspekt psychologiczny. To, w jakim decydent znajduje się środowisku oraz jakie czynniki na niego wpływają, odgrywa tutaj niezwykle istotną rolę. Błędy wynikające ze źle zaplanowanych działań często nie są winą jedynie niewiedzy decydenta, ale także tego, co nim kierowało w danym momencie. Zachowania człowieka podejmującego decyzję zależą przede wszystkim od trzech czynników, którymi są [Nosal, 1993, s. 179-186]:

1) struktury zadania,

2) osobowość jednostki i jej skłonność do ryzyka,

3) środowisko, w jakim działa człowiek w momencie podjęcia danej decyzji.

Planowanie i podejmowanie decyzji nie jest domeną tylko osób zarządzających przedsiębiorstwami, ale każdego pracownika. Należy więc podkreślić, że wszyscy zatrudnieni w firmie ludzie każdego dnia podejmują decyzje związane z ich miejscem pracy. W związku z tym właściciel bądź menadżer powinien motywować swoich podwładnych do tego, aby ich decyzje dobrze wpływały na całe przedsiębiorstwo.

Oprócz odpowiedniej motywacji występuje wiele innych czynników skorelowanych z zachowaniami ludzi podczas podejmowania decyzji. W wielu przypadkach błędy wynikające ze źle zaplanowanych działań są spowodowane niewiedzą decydentów. Sytuacja taka ma miejsce, gdy w przedsiębiorstwie nie ma rozwiniętej na odpowiednim poziomie komunikacji między pracownikami.

Zgodnie z literaturą przedmiotu zachowania człowieka podejmującego decyzje, zależą od struktury zadania, z jakim ma on do czynienia. Chodzi tutaj konkretnie o to, czy dla danej jednostki sytuacja do rozwiązania lub zaplanowania nosi rangę zadania trudnego czy łatwego. Należy pamiętać przy tym, że pracownicy zatrudnieni $\mathrm{w}$ organizacji mają bardzo różne doświadczenia, osobowości, środowiska, w których żyją, a dodatkowo są skłonni podejmować ryzyko w różnym stopniu. Wskutek tego każdy wyobraża sobie w nieco inny sposób, jak powinna wyglądać rzeczywistość w zderzeniu ze zdarzeniami podobnymi do zachodzących w przeszłości [Kahneman, Tversky, 1973, s. 251-273]. Zajścia z przeszłości w żadnym stopniu nie odpowiadają za to, co wydarzy się w przyszłości. Mimo tego wielu decydentów jest błędnie prze- 
świadczonych, że istnieje taka prawidłowość. Warto więc podkreślić, że wiedza, jaką posiada jednostka, jej usposobienie, wpływ społeczny i kulturowy, jaki jest na niej wywierany, oraz to, w jakim miejscu się aktualnie znajduje, może przyczyniać się do podjęcia różnych decyzji dotyczących tej samej kwestii.

Podobnym błędem wynikającym z nadinterpretacji są błędy statystyk. Za przykład można wziąć dwie sytuacje - pierwszą, że 6 na 10 ekspertów uważa, że dana decyzja będzie najlepsza oraz drugą, że 1200 z 2000 ekspertów jest zdania, że dana decyzja będzie najlepsza. Mimo że zarówno w pierwszej, jak i drugiej sytuacji o słuszności danego rozwiązania zadecydowało $60 \%$ znawców, to należy zwrócić uwagę, jak ogromna była różnica w liczbie badanych.

Gdyby wziąć pod uwagę wszystkie podkreślone uwarunkowania, można by stworzyć listę kilku błędów, które zmniejszają skuteczność podejmowania decyzji. Wymienić można poniższe [Robbins, 2005, s. 111-114]:

1. Decydenci zapominają, że decyzje określają, jaki przedsiębiorstwo będzie miało wizerunek, dlatego powinny być starannie podejmowane. Decydenci nie mogą zapominać, że za kroki, jakie przedsiębiorą, nie ponoszą wyłącznej odpowiedzialności, gdyż za złe podejście odpowie cała organizacja, choćby utratą klientów.

2. Unikając wysiłku i trudnych sytuacji, decydenci polegają na swoim doświadczeniu i przeczuciach. Intuicja ludzka jest zawodna, dlatego stwarzanie sobie „drogi na skróty” nie jest dobrym pomysłem, zwłaszcza jeśli chodzi o kluczowe kwestie.

3. Decydenci powinni ograniczyć zaufanie do innych osób wspierających i nie ograniczać się do ich zdania. Jednak ważne jest sprawdzanie tego, co mówią, i szukanie rozwiązań w różnych miejscach. Psychologia stoi bowiem na stanowisku, że jeśli człowiek mówi, że ma $100 \%$ pewności, to zazwyczaj jest to $75-80 \%$.

4. Osoby podejmujące decyzje muszą zwracać uwagę na konsekwencje długofalowe, a nie tylko chwilową satysfakcję, co nie zdarza się często. Przedsiębiorstwo zadowolone z nagłych zwiększonych zysków może nagle po czasie odkryć złe aspekty, które okazują się nieodwracalne.

5. Po podjętej decyzji upoważnieni dyrektorzy szukają potwierdzenia, czy ich założenie było słuszne. Niestety, prawidłowością jest, że owego potwierdzenia szuka się w miejscu, gdzie najprawdopodobniej usłyszy się to, czego się oczekuje. Taka sytuacja doprowadza do braku możliwości zniwelowania ewentualnych zagrożeń. 
6. Decydenci muszą pamiętać, że podejmowane decyzje dotyczą tylko przyszłości, dlatego do myślenia nie mogą wkradać się koszty i straty z dawnych czasów.

7. Negatywne emocje prowadzą do ograniczeń, przez co proces podejmowania decyzji jest przyspieszony, a działania pochopne. Jeżeli w grupie podejmującej decyzje pojawiają się złe emocje, najpierw należy je uspokoić, a następnie zacząć omawiać nurtujące tematy.

8. Kluczowe decyzje są w pewnych wypadkach nieodróżniane od pozostałych, prowadzi to do sytuacji, że organizacja zajmuje się różnymi sprawami, ale zbyt mało czasu poświęca tym naprawdę ważnym.

9. Jeśli omawiana sytuacja jest bardzo złożona i problematyczna, to zazwyczaj konstruuje się jej uproszczony model i bierze pod uwagę tylko podstawowe aspekty, omijając wszelkiego rodzaju zawiłości mogące stanowić sedno problemu. Rozwiązując taki dylemat, należy zwracać uwagę na każdy szczegół, poświęcić nawet więcej czasu na tę kwestię, aby uniknąć w ten sposób popełnienia diametralnego błędu.

Wielokrotnie w procesie podejmowania decyzji decydenci mają do czynienia z dużą liczbą możliwych do wyboru wariantów, która nie pozwala na dokładne przeanalizowanie każdego z osobna [Strelau, Doliński, 2010, s. 485-487]. W takim wypadku najlepsza do zastosowania może okazać się strategia zaproponowana przez Herberta Simona, dzięki której po przejrzeniu wszystkich możliwych wersji, wybrana zostaje opcja najbardziej satysfakcjonująca. Od razu nasuwa się jednak pytanie, dla kogo wybór ten będzie najlepszy. Może okazać się bowiem, że zadowoleni będą pracownicy tylko jednego działu w firmie. Można więc założyć, że wybór powinien być wystarczający z punktu widzenia potrzeb organizacji. W wielu przypadkach, niestety, nie zostaje wybrana najlepsza alternatywa. Szybkie znalezienie rozwiązania pozwala jednak zaoszczędzić cenny dla przedsiębiorstwa czas.

Jeszcze jednym zagadnieniem związanym z procesami decyzyjnymi i psychologiczną stroną tego tematu jest kwestia oceniania. Pozwala ono na wybór jak najlepszego rozwiązania problemu. Nie zawsze jednak jest to łatwe. Trudnościami, jakie mogą się tutaj pojawić, są błędy w ocenianiu. Przykładem takiego błędu może być sytuacja, kiedy decydenci mają do czynienia z kosztownym rozwiązaniem danego problemu, a następnie napotykają o wiele tańsze. Często w takiej sytuacji nie jest brana pod uwagę efektywność i ryzykowność, a najważniejszą determinantą okazuje się cena. Mamy tutaj do czynienia z tak zwaną zasadą kontrastu, gdzie duża 
różnica (w tym przypadku kosztowa) w jednej zmiennej wpływa na ostateczny wybór. Innym przykładem może być zdarzenie, kiedy decydenci biorą za najlepsze rozwiązanie to, które zostało przedstawione przez najatrakcyjniejszą z osób lub powierzchownie wygląda najlepiej. W tym wypadku mamy do czynienia z efektem aureoli, w myśl którego człowiek polega na złudnym przeświadczeniu, że coś z wyglądu atrakcyjniejsze jest automatycznie lepsze.

Wybór odpowiedniego rozwiązania może być również zakłócony poprzez schematy błędnych decyzji, którymi są [Rathus, 2006, s. 712-713]:

- zwycięstwo większości - podjęta zostaje decyzja, na którą głosowało więcej osób,

- zwycięstwo prawdy - wraz z napływem informacji decydenci orientują się w temacie i podejmują decyzję,

- reguła pierwszego przesunięcia - decyzja zostaje podjęta według pierwszej zmiany opinii jednego z członków grupy.

Warto podkreślić także rolę heurystyk w podejmowaniu decyzji. Są nimi nieświadomie stosowane uproszczenia w postępowaniu, które można nazwać także „drogami na skróty” [http://www.charaktery.eu/slownik-psychologiczny/H/124/Heurystyka/]. Są one dość niebezpieczne dla podjęcia trafnej decyzji, ponieważ mogą zawoalować prawdziwość niektórych sytuacji. Przykładem heurystyki może być zasada reprezentatywności, według której decydent podejmuje decyzję, biorąc pod uwagę podobieństwo rozwiązań do przypadku typowego, który jest mu znany.

\section{PLANOWANIE I PODEJMOWANIE DECYZJI W PRAKTYCE}

Planowanie i podejmowanie decyzji to procesy, które są obecne w każdym przedsiębiorstwie, niezależnie od jego wielkości czy branży, w jakiej działa. Każdego dnia pracownicy wszystkich szczebli podejmują inicjatywy dotyczące utrzymania nabywców, zdobycia nowych klientów czy zachowania porządku w organizacji. Wszystko to wiąże się z omawianymi powyżej kwestiami.

Zaawansowanie procesów planowania i podejmowania decyzji stanowi część badania przeprowadzonego na potrzeby stworzenia pracy dyplomowej autorki artykułu. Empiria pokazuje, w jak małym stopniu decydenci w przedsiębiorstwach planują poszczególne działania, a w jak dużej mierze to, co dzieje się wewnątrz firmy, jest efektem przypadku. 
Kluczowym zagadnieniem poruszonym w kwestionariuszu ankietowym było, czy w badanych przedsiębiorstwach zauważalne jest planowanie decyzji. Czy ktokolwiek informuje pracowników o tym, jakie zmiany mają zaistnieć? Ponad 50\% respondentów odpowiedziało, że nie zauważa żadnych planów ani projektów wdrożeniowych, a wszelkie decyzje podejmowane są ad hoc. Rozpoznanie takie świadczy albo o rzeczywistym braku scenariuszy działań, albo o bardzo złej komunikacji wewnątrz organizacji, co również nie przyczynia się do jej sukcesu.

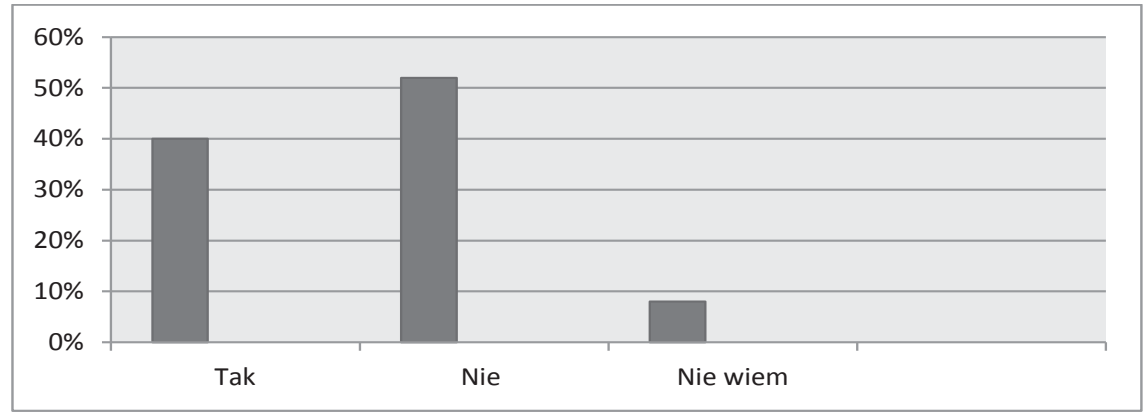

Wykres 1. Istnienie planowania w przedsiębiorstwie

Źródło: opracowanie własne na podstawie przeprowadzonych badań.

$\mathrm{Na}$ to, jak pracownicy utożsamiają się ze swoją pracą oraz czy ją w pełni akceptują, wpływ ma także możliwość oddziaływania na sytuację w przedsiębiorstwie. Poczucie ważności wpływa na zaangażowanie w zadaniach, które się wykonuje. Tego problemu dotyczyło kolejne pytanie, mające na celu uzyskanie informacji, czy przed podjęciem decyzji pracownicy są o nich powiadamiani i mogą wyrazić na ich temat swoje zdanie. Odpowiedzi nie są satysfakcjonujące, jeżeli patrzy się na nie od strony dobrego zarządzania organizacją oraz podejścia do pracowników. Tylko 7,8\% respondentów odpowiedziało, że mające wejść w życie decyzje są omawiane bądź chociaż przekazywane ogółowi. $63 \%$ osób odpowiedziało, że tylko niektóre decyzje są omawiane ze wszystkimi pracownikami. Nasuwa się tu jednak od razu pytanie, kto orzeka o tym, które decyzje są ważne, a które nie z punktu widzenia pracowników. Przecież może się tak zdarzyć, że decydenci uznają za nieznaczącą wiadomość, która w rzeczywistości jest kluczowa dla osób na niższych szczeblach. Ponadto 19,2\% odpowiadających napisało, że żadnych decyzji nie omawia się z pracownikami, a 10\% osób nie miało zdania. 


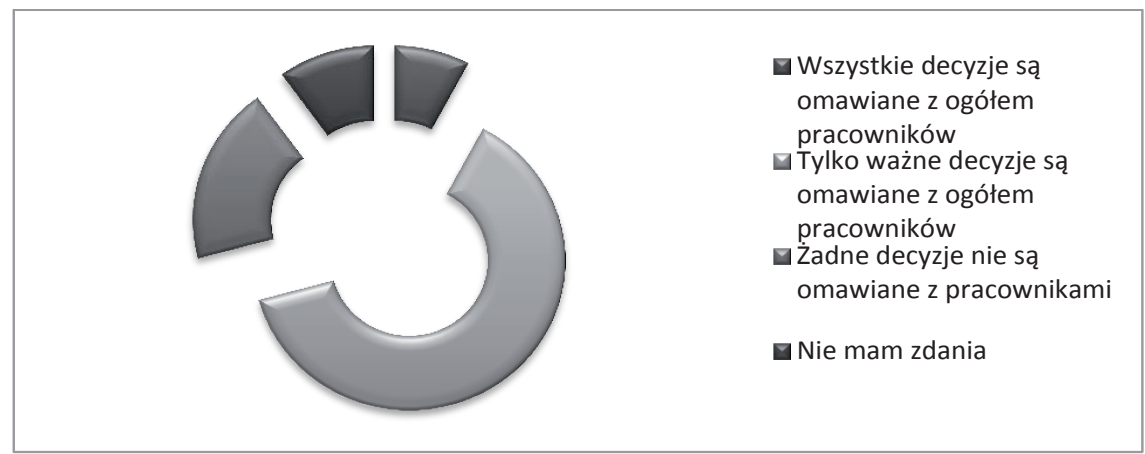

Wykres 2. Informowanie pracowników o przyszłości firmy

Źródło: opracowanie własne na podstawie przeprowadzonych badań.

W odpowiedzi na pytanie o możliwość zgłaszania własnych pomysłów i planów przez pracowników przedsiębiorstw respondenci w $76 \%$ odpowiedzieli, że taka istnieje. W wielu wypowiedziach znalazła się opinia, że sposobność zgłaszania idei ma każdy pracownik. Dodatkowo respondenci wypisali poniższe zagadnienia:

- „wszystkie zgłoszone pomysły są weryfikowane przez menadżera”,

- „pomysły są przyjmowane życzliwie i ze zrozumieniem”,

- ,pomysły są rozważane na forum pod kątem przydatności dla organizacji”,

- „pomysły są przyjmowane w zależności od tego, kto je proponuje”,

- „pomysły od pracowników są niekiedy wdrażane”,

- „pomysły są omawiane na zebraniach pracowników”.

Z powyższych wypowiedzi wynika, że pracownicy niejednokrotnie proponowali swoje pomysły i zazwyczaj nie byli z nimi odrzucani. Mając możliwość osobistego zaangażowania się w jakiś projekt, zatrudnieni łatwiej przyjmują zmiany, które jeśli wprowadzane są bez ich udziału i wiedzy, mogą powodować obawy i frustracje. 


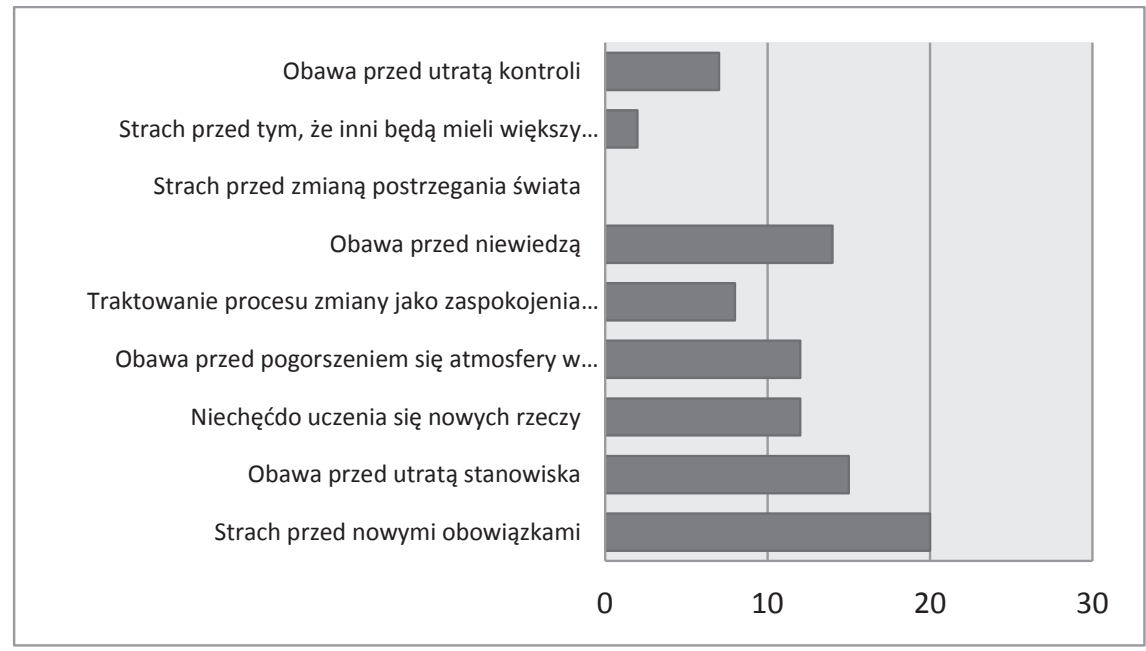

Wykres 3. Przyczyny strachu przed podejmowaniem nowych decyzji przez pracowników

Źródło: opracowanie własne na podstawie przeprowadzonych badań.

Właśnie w związku z podkreślonym strachem zadane zostało kolejne pytanie, które miało na celu ukazanie powodów niechęci do samodzielnego podejmowania decyzji lub brania na siebie odpowiedzialności. Zjawisko takie jest dość powszechnym i poważnym problemem w organizacjach, ponieważ może prowadzić do niekorzystnych zachowań wśród personelu i kierownictwa. Także i w badanych przedsiębiorstwach respondenci dostrzegają tę kwestię. Według nich niechęć do zmian wiąże się przede wszystkim z obawą przed nowymi obowiązkami - odpowiedziało tak $20 \%$ badanych. Równie wysokie wskazania uzyskał strach przed utratą stanowiska (15\%) oraz obawa przed niewiedzą (14\%). Drugi element został opisany jako zaniepokojenie tym, że inni będą posiadali szerszą wiedzę, czy będą posiadali nieudostępnione ogółowi informacje. Pozostałymi, ale również dość znaczącymi uwarunkowaniami są niechęć do uczenia się nowych rzeczy, które mogłyby być wymagane po podjęciu nowych decyzji (12\%), możliwość pogorszenia się atmosfery w miejscu pracy $(12 \%)$, obawa przed utratą kontroli $(7 \%)$ oraz traktowanie wprowadzonego przez pracownika pomysłu jako zaspokojenie jego indywidualnej, wyimaginowanej potrzeby (8\%). Niezbyt znaczącym uwarunkowaniem okazał się strach przed większym wpływem innych na sytuację w miejscu pracy $(2 \%)$. 
W przeprowadzonym badaniu respondentów zapytano również, czym dla nich jest proces planowania. Najczęściej powtarzającymi się odpowiedziami były:

- „realizacja uzyskania zakładowych wyników”,

- „określenie celów, sposobów ich realizacji”,

- „ustalanie działań w dłuższym okresie i sukcesywna ich realizacja”,

- „kalendarz działań na cały rok”,

- ,analiza SWOT”,

- „tworzenie wizji”,

- „doraźne, długofalowe przydzielanie zadań pracownikom”.

\section{PODSUMOWANIE}

Przeprowadzone badanie pokazało, że menadżerowie firm nie przykładają zbytniej wagi do procesów planowania i podejmowania decyzji. Większość pracowników nie dostrzega w ogóle istnienia jakichkolwiek procedur dotyczących określania i realizacji celów przedsiębiorstw.

Powodem braku chęci do podejmowania nowych decyzji w przedsiębiorstwach jest w głównej mierze strach przed nowymi obowiązkami. Wskazuje to na fakt, że pracownicy nie zwracają uwagi na to, czy sytuacja firmy się poprawi, a najważniejsze dla nich jest zachowanie starego ładu zadaniowego.

Przeprowadzone badania pozwoliły ustalić, że w przedsiębiorstwach brakuje podstawowej rzeczy - komunikacji między poszczególnymi szczeblami. Można zauważyć, że jest to przeszkoda w wygenerowaniu większej liczby dobrych pomysłów.

Reasumując dotychczasowe rozważania, podkreślić należy złożoność procesów planowania i podejmowania decyzji zarówno od strony czysto zarządczej, jak i zarządczo-psychologicznej. Większa współpraca i możliwość zaangażowania wszystkich pracowników w zmiany w przedsiębiorstwie mogłaby przynieść znaczące korzyści i efekty. 


\section{LITERATURA}

Czermiński A., Czerska M., Nogalski B., Rutka R., Apanowicz J., (2002), Zarzqdzanie organizacjami, Towarzystwo Naukowe Organizacji i Kierownictwa Dom Organizatora, Torun.

Kahn R., Katz D., (1976), Społeczna psychologia organizacji, PWN, Warszawa.

Kahneman D., Tversky A., (1973), On the Psychology ofPprediction, "Psychological Review", New York

Kotarbiński T., (1960), Sprawność i bład, PZWS, Warszawa.

Kozielecki J., (1992), Podejmowanie decyzji, [w:] Tomaszewski T. (red.) Percepcja, myślenie, decyzje, Wydawnictwo Naukowe PWN, Warszawa.

Kuczmera-Ludwiczyńska E., Romanowska M., Sopińska A., Wachowiak P., (2001), Podejmowanie decyzji w organizacji, Difin, Warszawa.

Nosal C. S., (1993), Umyst menedżera. Problemy - decyzje - strategie, Wrocławskie Wydawnictwo „Przecinek”, Wrocław.

Rathus S. A., (2006), Psychologia wspótczesna, GWP, Gdańsk.

Robbins S. P., (2005), Skuteczne podejmowanie decyzji, PWE, Warszawa.

Strelau J., Doliński D., (2010), Psychologia akademicka, GWP, Gdańsk.

Stroński M., (2011), Plany sprzedażowe jako podstawowa determinanta łamania etyki w sektorze bankowości i finansów, Warszawa.

Sudolska A., (2013), Social CRM jako nowoczesna koncepcja biznesowa, „AUNC Zarządzanie XL, Zeszyt 413”,

Tyrała P., (2001), Kierowanie. Organizowanie. Zarzadzanie, Wydawnictwo Adam Marszałek, Torun.

Załęski W., (1993), Zarządzanie przez cele przedsiębiorstwem. Poradnik metodyczny, Oficyna Wydawnicza Ośrodka Postępu Organizacyjnego, Bydgoszcz.

Zieleniewski J., (1969), Organizacje, PWN, Warszawa.

\section{ŹRÓDŁA ELEKTRONICZNE}

http://encyklopedia.pwn.pl/haslo.php?id=3965198 [14.02.2011].

http://www.is.uw.edu.pl/wp-content/uploads/21_Bierzynski.pdf [15.04.2014]

http://www.ekonsument.pl/a66763_czy_moda_kocha_lasy.html [13.04.2014].

http://www.ekonsument.pl/a66758_analiza_wlokien_potwierdzila_ze_notatni-

ki_ikea_zawieraja_celuloze_z_lasow_tropikalnych.html [15.04.2014]. 


\title{
THE PROCESS OF PLANNING AND DECISION-MAKING IN THE ENTERPRISE AS THE MAIN ELEMENTS OF MANAGEMENT
}

\begin{abstract}
A bstract: The goal of this article is to show how important and complex the processes of planning and decision making for an enterprise are. Moreover, the article also presents a psychological side which is not very well described in the management but which plays a significant role. The combination of this perception with the traditional description completes plans, objectives and decisions for enterprises.
\end{abstract}

K e y w o r d s: decision making; planning; goals; rules of decision-making. 